\title{
Date and plant community effects on elk sedge forage quality
}

\author{
PATRICK E. CLARK
}

Author is Range Scientist, USDA Agricultural Research Service, 800 Park Blvd., Plaza IV, Suite 105, Boise, Ida. 83712.

\begin{abstract}
Elk sedge (Carex geyeri Boott) is one of the most important livestock and big game forages in many areas of the western U.S. It is one of the most prominent forage species in the diets of cattle and elk utilizing forested rangelands. Despite its acknowledged ecological and economical importance, very little is known about the factors influencing the forage quality of elk sedge. Effects of sampling date, plant community, and their interaction on the neutral detergent fiber, acid detergent fiber, and crude protein levels of elk sedge are reported for samples collected at the Starkey Experimental Forest and Range and the Bridge Creek Wildlife Management Area, both in northeastern Oregon, during January, April, July, and October of 1997 and 1998. Neutral detergent fiber levels in elk sedge were lowest in mid-October $(\overline{\mathbf{x}}=\mathbf{7 1 . 3 \%})$ and highest in mid-July $(\bar{x}=76.1 \%)$. Acid detergent fiber was lowest in elk sedge collected in mid-October $(\overline{\mathbf{x}}=37.3 \%)$ and highest in mid-July $(0=39.0 \%)$ and mid-January $(\bar{x}=39.2 \%)$. Elk sedge from the Douglas-fir/ninebark community was lowest in acid detergent fiber $(\overline{\mathbf{x}}=38.1 \%)$. Crude protein was highest $(0$ $=8.0 \%)$ in mid-July elk sedge samples and lowest $(\bar{x}=5.7 \%)$ in mid-January samples. Elk sedge from the ponderosa pine/fescue community was lowest in crude protein $(\bar{x}=5.9 \%)$. All forage quality parameters exhibited variability between years. Although sampling date and plant community effects were detected, the forage quality of elk sedge appeared relatively stable compared to other native forages. A more intensive spring sampling campaign is needed to characterize the relationship between elk sedge phenology and forage quality dynamics.
\end{abstract}

Key Words: Carex geyeri, cattle, graminoids, nutrition, phenology, season

Elk sedge (Carex geyeri Boott) is one of the most important forages for livestock and big game in northeastern Oregon (Pickford and Reid 1943, Edgerton and Smith 1971, Skovlin et al. 1976, Skovlin and Vavra 1979) and other areas of the western U.S. (Kufeld 1973). Elk sedge has been noted as the most prominent forage species in the diets of cattle (Bos taurus L.) on summer range in northeastern Oregon (Skovlin et al. 1976). Cattle may consume from 4 to $23 \%$ of their summer diet as elk sedge

This research was conducted with the cooperation of the USDA Forest Service and Oregon Dept. Fish and Wildlife. Funding was provided by the USDA Agricultural Research Service and USDA Forest Service.

The author wishes to thank David Harcombe and Brian Dick for their sound advice and logistical support and David Ganskopp, Steve Seefeldt and two anonymous reviewers for their critical review and comments on drafts of this manuscript.

Manuscript accepted 24 Mar. 02.
Resumen

En muchas áreas del oeste de Estados Unidos el "Elk sedge (Carex geyeri Boott) es uno de los forrajes mas importantes para el ganado y la fauna mayor. Es una de las especies forrajeras mas prominentes en las dietas del ganado y alces que utilizan los pastizales boscosos. A pesar de su conocida importancia económica y ecológica se sabe muy poco respecto a los factores que influyen en la calidad del forraje del "Elk sedge". Se reportan los efectos de la fecha de muestreo, comunidad vegetal y sus interacciones en los niveles de fibra neutro detergente, fibra ácido detergente y proteína cruda de "Elk sedge" de muestras colectadas en la Estación Experimental Forestal y de Pastizales Starkey y en el área de Manejo de Fauna Silvestre de Bridge Creek, ambas situadas en el nordeste de Oregon. Los muestreos se realizaron durante Enero, Abril, Julio y Octubre de 1997 y 1998. Los niveles mas bajos de fibra neutro detergente del "Elk sedge" se presentaron a mediados de Octubre $(\overline{\mathrm{x}}=\mathbf{7 1 . 3 \%})$ y los mas altos a mediados de Julio $(\overline{\mathbf{x}}=\mathbf{7 6 . 1 \%})$. Los niveles mas bajos de fibra ácido detergente presentaron en el "Elk sedge" colectado a mediados de Octubre $(\bar{x}=37.3 \%)$ y los mas altos en el colectado a mediados de Julio $(\bar{x}=39.0 \%)$ y mediados de Enero $(\bar{x}=39.2 \%)$. El "Elk sedge"colectado en comunidades de " Douglas-fir/ninebark" fue el que presento los niveles mas bajo de fibra ácido detergente $(\bar{x}=38.1 \%)$. El contenido de proteína cruda mas alto se obtuvo en las muestras colectadas a mediados de Julio $(\bar{x}=8.0 \%)$ y el mas bajo en las colectadas a mediados de Enero $(\bar{x}=5.7 \%)$. El "Elk sedge" proveniente de la comunidad de "Pine/fescue" fue el mas bajo en proteína cruda $(\bar{x}=5.9 \%)$. Todos los parámetros de calidad de forraje mostraron variabilidad entre años. Aunque se detectaron efectos de la fecha de muestreo y la comunidad vegetal, la calidad del forraje del "Elk sedge" parece relativamente estable comparada con otros forrajes nativos. Se necesita una campaña de muestreo mas intensiva durante la primavera para caracterizar las relaciones entre la fonología del "Elk sedge" y la dinámica de la calidad del forraje.

while fall diets may contain 17 to $24 \%$ elk sedge (Holechek et al. 1982). Seasonal diets of Rocky Mountain elk (Cervus elaphus nelsoni Bailey) may contain 11 to $21 \%$ elk sedge in spring, 12 to $24 \%$ in summer, 18 to $46 \%$ in fall and from 0 to $30 \%$ in winter (McArthur 1977, McReynolds 1977, Sheehy 1987). Despite this acknowledged importance, little is known about the variability in elk sedge forage quality or the factors influencing this variability.

Forage quality greatly influences rangeland carrying capacity and forage and habitat utilization patterns of livestock (Pinchak et at. 1991, Bailey et al. 1996) and big game (Hobbs and Swift 1985, Larter and Gates 1991). Forage quality of nearly all herbage varies throughout the year. A limited amount of seasonal forage quality data has been collected for elk sedge in northeast- 
ern Oregon (Skovlin 1967, Clark et al. 2000) and central Washington (McArthur 1977, McReynolds 1977). Our understanding of the forage quality trends of elk sedge, however, has been confined to late spring through fall.

By definition, biotic and abiotic conditions differ between vegetation or plant communities and these conditions may influence the forage quality of component species. Researchers in Montana have compared total nonstructural carbohydrate levels in elk sedge from different vegetation types (Krueger and Bedunah 1988), but the forage quality responses of elk sedge to differing vegetation or plant communities have not been evaluated. The objective of this study was to examine the influence of sampling date, plant community, and their interaction on the neutral detergent fiber (NDF), acid detergent fiber (ADF), and crude protein (CP) levels of elk sedge.

\section{Materials and Methods}

\section{Study Areas}

The study was conducted at 2 study areas; Starkey Experimental Forest and Range (hereafter referred to as Starkey; $\left.45^{\circ} 35^{\prime} \mathrm{N}, 118^{\circ} 30^{\prime} \mathrm{W}\right)$ near La Grande, Ore., and Bridge Creek Wildlife Management Area (hereafter referred to as Bridge Creek; $45^{\circ} 03^{\prime} \mathrm{N}, 118^{\circ} 55^{\prime} \mathrm{W}$ ) near Ukiah, Ore. Starkey is a USDA Forest Service research area $\left(101 \mathrm{~km}^{2}\right)$ where forage and habitat use by livestock, elk, and mule deer (Odocoileus hemionus hemionus Rafinesque) have been monitored since 1940 (Skovlin 1991). Bridge Creek (33 $\mathrm{km}^{2}$ ) has been owned by the Oregon Department of Fish and Wildlife since 1961 and is primarily managed as an elk range where late spring grazing by livestock has been closely-monitored since 1964 (Anderson and Scherzinger 1975).

Climate at both study areas is continental with maritime influences. Winters are cold and wet with more than half of the annual precipitation falling as snow between November and March (Fig. 1). Summers are warm and dry. The growing season is about 120 days but frost can occur during any month of the year.

Elevation at Starkey ranges from 1,150 to $1,700 \mathrm{~m}$ while Bridge Creek lies between 850 and 1,200 $\mathrm{m}$. The landscape at both study areas consists of a dissected basaltic plateau with broad ridges and steep, narrow drainages typical of the interior Blue Mountains and much of the Columbia Basin at mid elevations (800 to

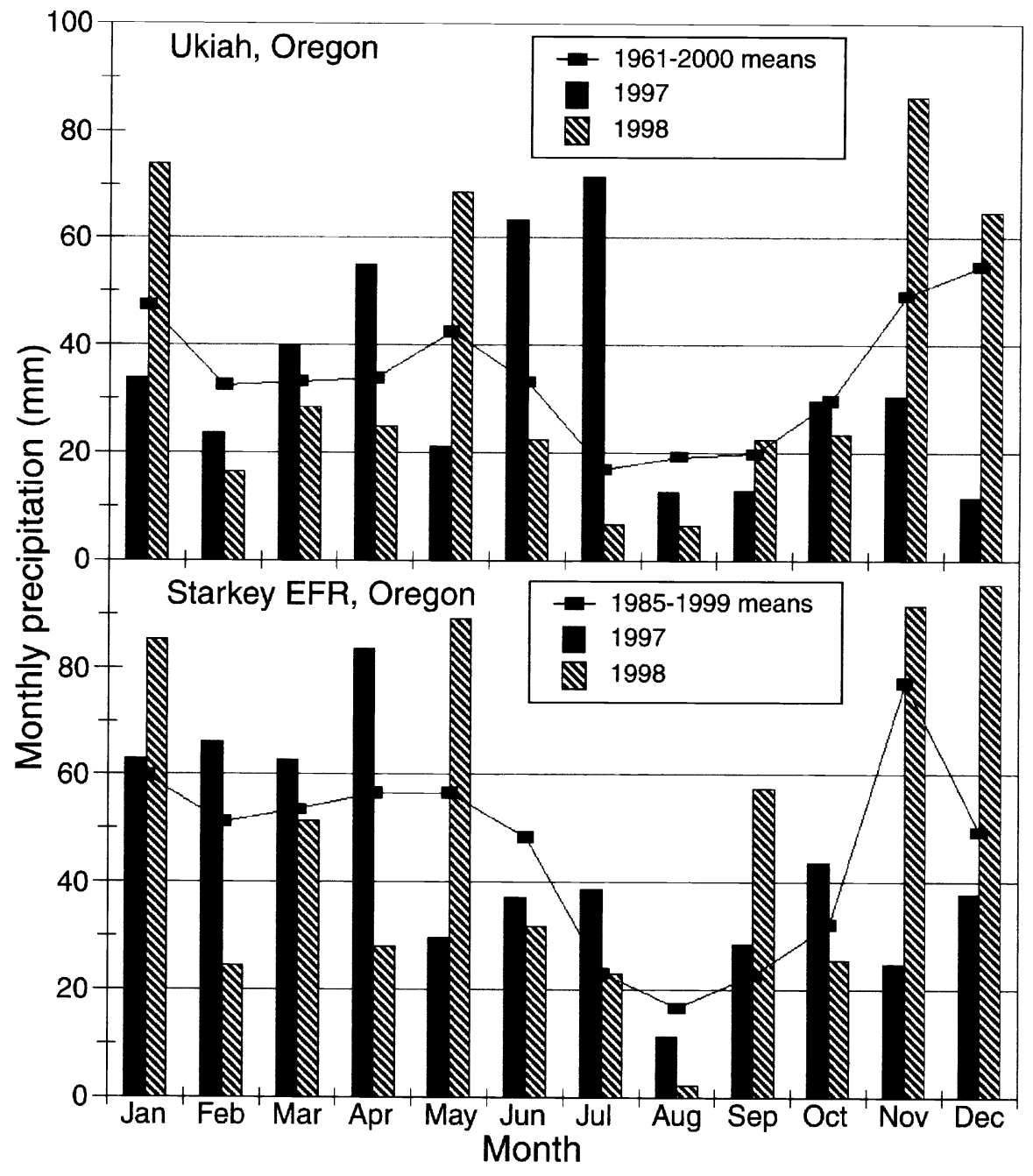

Fig. 1. Monthly precipitation for 1997-1998 and long-term mean monthly precipitation for Ukiah, Oregon, and Starkey Experimental Forest and Range, Oregon.

$1,800 \mathrm{~m})$. Soils at Starkey range from shallow silty clay loams and heavy clays on the ridges to silty clays and clay loams of variable depth on the steep, forested drainage slopes (Skovlin 1991). At Bridge Creek, ridgetop soils are shallow, very stony loams or relatively deep silt loams overlying basalt. Soils on the steep slopes range from shallow, stony loams to deep silt loams depending on exposure (Anderson and Scherzinger 1975).

Bunchgrass grasslands occupy the broad ridges of both study areas while ponderosa pine (Pinus ponderosa Dougl.), Douglasfir (Pseudotsuga menziesii [Mirbel] Franco.) and grand fir (Abies grandis [Douglas] Forbes) forests occur in the drainages and on the highlands. Plant communities of interest for the current study were: 1) ponderosa pine/fescue (Festuca spp.), 2) Douglas-fir/ninebark (Physocarpus malvaceus [Greene]
Kuntze), and 3) mixed conifer/pinegrass (Calamagrostis rubescens Buckl.) communities. These communities occur extensively throughout the region and contain elk sedge as an understory dominant or codominant. The ponderosa pine/fescue community occupies the upper slopes of the study area drainages, forming a pine/bunchgrass savanna at the interface between ridgetop grasslands and coniferous forest. Vegetation in this community consists of a ponderosa pine overstory and an understory of Idaho fescue (Festuca idahoensis Elmer), elk sedge, and bluebunch wheatgrass (Pseudoroegneria spicata [Pursh] A. Löve) (Hall 1973: CP-G112). The Douglas-fir/ninebark community occurs on canyon slopes and is more extensive on the drier aspects. The Douglas-fir/ninebark community supports Douglas-fir, ponderosa pine, and grand fir with a shrub layer of ninebark, common 


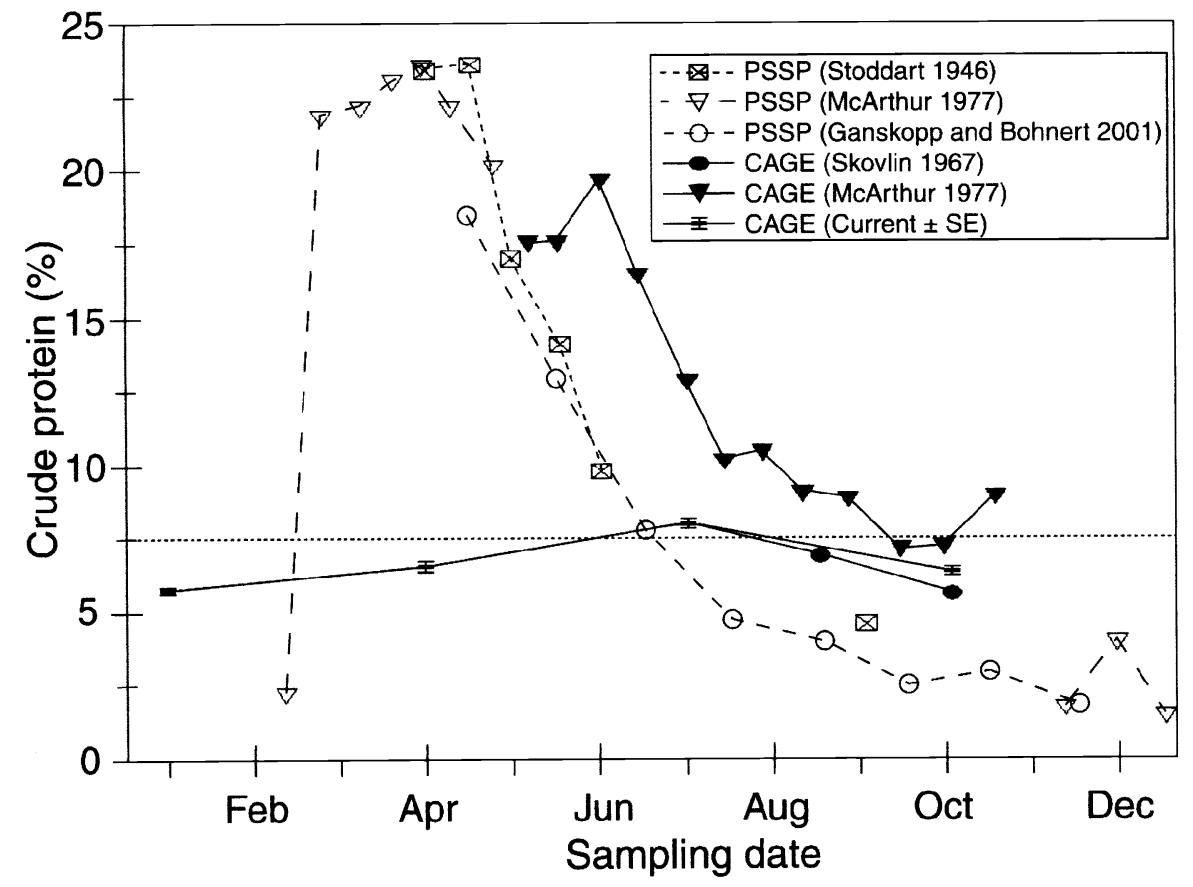

Fig. 2. Sampling date trends in crude protein (\%) for elk sedge (CAGE) collected in central Washington and northeastern Oregon and for bluebunch wheatgrass (PSSP) collected in northern Utah, central Washington, and southeastern Oregon. The dashed horizon line represents the $\mathbf{7 . 5 \%}$ crude protein threshold for maintenance diets.

snowberry (Symphoricarpos albus [L.] Blake), and oceanspray (Holodiscus discolor [Pursh] Maxim.) with a herbaceous layer of elk sedge and pinegrass (Hall 1973: CD-S7-11). The canyon bottoms and north slopes of the study areas are occupied by the mixed conifer/pinegrass community. Douglas-fir, grand fir and ponderosa pine form the overstory in this community with elk sedge and pinegrass making up the understory. No shrub layer occurs in the mixed conifer/pinegrass community (Hall 1973:CW-G1-11).

\section{Sample Collection}

Digital plant community maps of Starkey and Bridge Creek were developed in a GIS using 1:12,000 scale, color aerial photographs and extensive groundtruthing. At each of the 2 study areas, 3 plant community mapping units were randomly selected as sampling sites for each of the ponderosa pine/fescue, Douglasfir/ninebark, and mixed conifer/pinegrass plant community types. A randomly located base line was established within each sampling site. During each sampling campaign, elk sedge at a site was sampled along 4 transects originating from 4 random locations along the baseline. At 5 random points along each transect, all the elk sedge standing crop within $0.5 \mathrm{~m}^{2}$ cirforage quality trends of elk sedge from late spring to early fall are available (Skovlin 1967, McArthur 1977, McReynolds 1977). Forage quality of elk sedge during early spring (April) has peak forage quality in elk sedge is unknown. The mid-April sampling campaign of the current study was an attempt to capture elk sedge during its expected annual peak in forage quality. The timing of this campaign was selected by examining the forage quality trends of elk sedge, pinegrass, and bluebunch wheatgrass using data collected by McArthur (1977) and McReynolds (1977) in central Washington and bluebunch wheatgrass data collected in northern Utah by Stoddart (1946) (Fig. 2).

\section{Laboratory Analysis}

Samples were oven dried at $45^{\circ} \mathrm{C}$, ground to pass a $1-\mathrm{mm}$ screen, and stored in air-tight bags. Neutral detergent fiber (Robertson and Van Soest 1981) and ADF (Goering and Van Soest 1970) analyses were conducted using procedures modified for use in an Ankom 200 Fiber Analyzer (Ankom Co., Fairport, N.Y. ${ }^{1}$ ). Neutral detergent fiber describes the cell wall content of a forage including cellulose, lignin, and hemicellulose (Van Soest 1982). Acid detergent fiber is a measure of the cellulose and lignin content of a forage and is inversely related to the digestible dry matter (DDM) content (Van Soest 1982). Crude protein was determined in duplicate using a LECO carbon/nitrogen analyzer (LECO Corp., St. Joseph, Mich.). Crude protein, NDF, and ADF values were reported on a dry matter basis.

\section{Statistical Analysis}

Forage quality data were analyzed with a split-plot in time analysis procedure (PROC MIXED; SAS 1997) where study areas $(n=2)$, years $(n=2)$, and plant communities $(n=3)$ were assigned as whole plot factors and sampling dates $(n=4)$ were subplot factors. The sites within year, study area and plant community term with 24 degrees of freedom (Satterthwaite 1946) was designated as a random effect in the mixed model and became the error term for testing the main effects of year, study area, plant community and their interactions. The residual with 72 degrees of freedom (Satterthwaite 1946) was used as the error term for date and all interactions involving date. Where significant main effects or interactions were detected, Tukey's HSD procedure was used for all mean separations (Tukey 1953). All differences reported were significant at $\mathrm{P}<$ 0.05 unless stated otherwise. never been characterized and the timing of
Mention of manufactures or trade names is for the convenience of the reader only and implies no endorsement on the part of the author or USDA. 


\section{Results}

\section{Neutral Detergent Fiber}

Neutral detergent fiber of elk sedge was influenced by sampling date $(\mathrm{P}<0.01$, SE $=0.33 \%)$ and year $(\mathrm{P}<0.01, \mathrm{SE}=0.24 \%)$ but was unaffected by plant community $(\mathrm{P}$ $=0.99, \mathrm{SE}=0.29 \%)$ or study area $(\mathrm{P}=$ $0.18, \mathrm{SE}=0.24 \%)$. Samples collected in mid-October $(\overline{\mathrm{x}}=71.3 \%)$ were lowest in NDF. Elk sedge harvested in January ( $\overline{\mathrm{x}}=$ $73.6 \%)$ and April $(\overline{\mathrm{x}}=73.2 \%)$ had similar NDF levels but was lower than that collected in July $(\bar{x}=76.1 \%)$. Levels of NDF were lower in $1998(\bar{x}=72.5 \%)$ than in $1997(\bar{x}=74.6 \%)$. No significant interactions for NDF were detected between any of the 4 main effects.

\section{Acid Detergent Fiber}

Differences in ADF of elk sedge were detected between sampling date $(\mathrm{P}<0.01$, $\mathrm{SE}=0.20 \%)$, among plant communities ( $\mathrm{P}$ $=0.02, \mathrm{SE}=0.17 \%)$, and between years $(\mathrm{P}<0.01, \mathrm{SE}=0.14 \%)$. Mid-October samples of elk sedge contained the lowest ADF levels $(\overline{\mathrm{x}}=37.3 \%)$ while April levels were intermediate $(\overline{\mathrm{x}}=38.4 \%)$ and July $(0$ $=39.0 \%)$ and January $(\bar{x}=39.2 \%)$ levels were highest. Elk sedge in the Douglasfir/ninebark plant community was lowest in $\operatorname{ADF}(\bar{x}=38.1 \%)$. Acid detergent fiber levels were similar in the ponderosa pine/fescue $(\bar{x}=38.7 \%)$ and mixed conifer/pinegrass $(\bar{x}=38.6 \%)$ communities. Elk sedge collected in $1998(\overline{\mathrm{x}}=$ $37.6 \%$ ) was lower in ADF than in $1997(\overline{\mathrm{x}}$ $=39.4 \%)$. A significant interaction between plant community and study area was detected for $\mathrm{ADF}(\mathrm{P}=0.03, \mathrm{SE}=$ $0.24 \%$ ) (Table 1).

\section{Crude Protein}

Crude protein of elk sedge was affected by sampling date $(\mathrm{P}<0.01, \mathrm{SE}=0.11 \%)$, plant community $(\mathrm{P}<0.01, \mathrm{SE}=0.10 \%)$, study area $(\mathrm{P}<0.01, \mathrm{SE}=0.08 \%)$, and year $(\mathrm{P}<0.01, \mathrm{SE}=0.08 \%)$. Samples collected in mid-July were highest in CP $(\overline{\mathrm{x}}=$
Table 2. Mean crude protein (CP) in elk sedge samples collected at Starkey Experimental Forest and Range and Bridge Creek Wildlife Management Area, Ore., during 1997 and 1998 as affected by sampling date-plant community interactions.

\begin{tabular}{|c|c|c|c|c|}
\hline \multirow[b]{2}{*}{ Plant Community } & \multicolumn{4}{|c|}{ Sampling Date } \\
\hline & Mid-Jan & Mid-Apr & Mid-Jul & $\overline{\text { Mid-Oct }}$ \\
\hline & 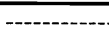 & - & 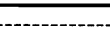 & -------- \\
\hline P. Pine/fescue ${ }^{1}$ & $5.5 \mathrm{~cd}^{2}$ & $5.8 \mathrm{~cd}$ & $7.0 \mathrm{~b}$ & $5.4 \mathrm{~d}$ \\
\hline D-fir/ninebark & $5.7 \mathrm{~cd}$ & $6.9 \mathrm{~b}$ & $8.6 \mathrm{a}$ & $6.7 b$ \\
\hline M. Conifer/pinegrass & $5.9 \mathrm{c}$ & $6.8 \mathrm{~b}$ & $8.4 \mathrm{a}$ & $6.6 b$ \\
\hline
\end{tabular}

P. Pine/fescue represents the ponderosa pine/Idaho fescue community, D-fir/ninebark represents the Douglasfir/ninebark community, and M. Conifer/pinegrass represents the mixed conifer/pinegrass community.

${ }^{2}$ Means sharing a common letter are not significantly different $(\mathrm{P}>0.05)$.
$8.0 \%)$ while mid-April $(\overline{\mathrm{x}}=6.5 \%)$ and mid-October $(\overline{\mathrm{x}}=6.3 \%)$ samples were similar but higher than elk sedge collected in mid-January $(\bar{x}=5.7 \%)$. Crude protein levels in the Douglas-fir/ninebark $(\overline{\mathrm{x}}=$ $7.0 \%)$ and mixed conifer/pinegrass $(\bar{x}=$ $6.9 \%$ ) plant communities were similar but higher than in the ponderosa pine/fescue community $(\bar{x}=5.9 \%)$. Elk sedge collected at Bridge Creek $(\bar{x}=6.9 \%)$ was higher in CP than at Starkey $(\bar{x}=6.3 \%)$. Percentage crude protein in samples harvested in 1998 $(\bar{x}=6.9 \%)$ was higher than in $1997(\bar{x}=$ $6.3 \%)$. Sampling date by plant community $(\mathrm{P}=0.03, \mathrm{SE}=0.19 \%$, Table 2$)$ and study area by year $(\mathrm{P}=0.05, \mathrm{SE}=0.12 \%)$ interactions affected CP levels of elk sedge. Elk sedge at Bridge Creek contained higher CP levels during $1998(\overline{\mathrm{x}}=7.3 \%)$ than $1997(\bar{x}=6.5 \%)$ while elk sedge at Starkey exhibited no CP differences between $1998(\bar{x}=6.5 \%)$ and $1997(\bar{x}=$ $6.2 \%$ ).

\section{Discussion}

\section{Forage Quality and Phenology}

Seasonal trends in ADF and CP of elk sedge at Starkey and Bridge Creek appear to differ from other dominant graminoids such as bluebunch wheatgrass. Forage quality of bluebunch wheatgrass tends to increase sharply from an annual low in late winter to a peak in early spring during the early vegetative growth stage (mid-
Table 1. Mean acid detergent fiber (ADF) in elk sedge samples collected at Starkey Experimental Forest and Range and Bridge Creek Wildlife Management Area, Ore., during 1997 and 1998 as affected by a plant community-study area interaction.

\begin{tabular}{lccc}
\hline \hline & \multicolumn{3}{c}{ Plant Community } \\
\cline { 2 - 4 } Study Area & P. Pine/fescue & D-fir/ninebark & M. Conifer/pinegrass \\
\hline & $-0.3 \mathrm{bc}^{2}$ & $38.1 \mathrm{c}$ & $38.8 \mathrm{ab}$ \\
Starkey & $39.2 \mathrm{a}$ & $38.0 \mathrm{c}$ & $38.4 \mathrm{bc}$ \\
\hline
\end{tabular}

${ }^{\mathrm{P}}$. Pine/fescue represents the ponderosa pine/Idaho fescue community, D-fir/ninebark represents the Douglasfir/ninebark community, and $\mathbf{M}$. Conifer/pinegrass represents the mixed conifer/pinegrass community.

${ }^{2}$ Means sharing a common letter are not significantly different $(P>0.05)$.
April), declines rapidly in late spring/early summer during reproductive stages (midJune), then more gradually declines through summer and fall back to the winter low (Stoddart 1946, McArthur 1977) (Fig. 2). Favorable soil moisture conditions may promote a fall peak in forage quality of bluebunch wheatgrass but this is uncommon in the Blue Mountains (Bryant 1993). Results from the current study suggest the forage quality of elk sedge in the Blue Mountains exhibits very slight peaks during summer or fall but generally is relatively stable. These results, however, may not fully reflect the forage quality dynamics of elk sedge. Although the phenology of elk sedge at Starkey and Bridge Creek was well advanced during midApril (most plants were in the spikelet emerging or anthesis stages), the midApril sampling date may have been too early to capture the actual peak in forage quality of elk sedge. Data presented by McArthur (1977) and McReynolds (1977) suggest the forage quality of elk sedge in central Washington probably peaks at levels somewhat lower than bluebunch wheatgrass and may do so in mid-June rather than in mid-April. The phenology of elk sedge was not reported in the central Washington studies, however, elk sedge at Starkey is typically nearing the ripe seed phenological stage by mid June (Driscoll 1957, Skovlin 1967). Given these observations, the relationship between forage quality and phenology of elk sedge appears to differ considerably from that of bluebunch wheatgrass and possibly other dominant graminoids in the region. Additional research is needed to investigate the relationships between forage quality and phenology in elk sedge.

\section{Plant Community Effects}

Although NDF levels in elk sedge were unaffected by plant community, ADF was lowest in the Douglas-fir/ninebark community and CP was highest in the Douglasfir/ninebark and mixed conifer/pinegrass 
communities. The Douglas-fir/ninebark and mixed conifer/pinegrass plant communities provide a more mesic growing season microclimate for elk sedge than the drier sites occupied by the ponderosa pine/fescue community. The understory in these 2 communities is typically well shaded and accumulated snow and soil moisture is likely conserved later into the year than in the ponderosa pine/fescue community. As observed in other studies (Clark et al. 2000), elk sedge in the more open ponderosa pine/fescue community appears to suffer more from desiccation and exposure, exhibiting more withered leaves or leaf tips, than elk sedge in the communities with denser tree canopies. More favorable growing conditions may allow elk sedge in the Douglasfir/ninebark and mixed conifer/pinegrass communities to be more vigorous, nutritious and sustain high forage quality longer through the year than elk sedge in the ponderosa pine/fescue community.

Plant community effects on ADF levels in elk sedge differed between Starkey and Bridge Creek (Table 1). Although elk sedge at Starkey and Bridge Creek exhibited similar ranges in ADF among plant communities, ADF was highest in the ponderosa pine/fescue community at Bridge Creek while the ponderosa pine/fescue community and mixed conifer/pinegrass communities were similar and highest in ADF at Starkey. This interaction of plant community and study area might be explained by differences in snow and soil moisture patterns. Bridge Creek is lower in elevation than Starkey and probably receives a lower and more spatially variable snowpack. Possible plant community effects on snow accumulation and soil moisture conservation may be more pronounced at Bridge Creek and may contribute to the greater forage quality variability observed among plant communities at Bridge Creek.

\section{Sampling Date by Plant Community Interactions}

Crude protein in elk sedge was similar among plant communities during midJanuary, but CP in elk sedge collected during all other sampling dates was higher in the Douglas-fir/ninebark and mixed conifer/pinegrass plant communities than in the ponderosa pine/fescue community (Table 2). Additionally, elk sedge in the Douglas-fir/ninebark and mixed conifer/pinegrass communities exhibited significant increases in CP by mid-April and maintained these increases through mid-October while $\mathrm{CP}$ increases for elk sedge in the ponderosa pine/fescue community were only detected at the mid-July sampling date. If the earlier, higher, and longer lasting CP increases observed in elk sedge from the Douglasfir/ninebark and mixed conifer/pinegrass communities were due to moister, more favorable microclimatic conditions in these communities, then these moister conditions may also promote increased rates of degradation and nutrient leaching during the winter months compared to those in the ponderosa pine/fescue community. Hence, differences in elk sedge CP levels observed among plant communities during the growing season would likely even out, as observed, during winter.

\section{InterAnnual Variability}

Forage quality differences, particularly in NDF and ADF levels, detected between years may be related to differences in the amount and timing of precipitation. Weather stations at Starkey and within 8 $\mathrm{km}$ of Bridge Creek experienced above normal precipitation during the early spring months of 1997 (Fig. 1). May of 1997, however, was abnormally dry. Spring precipitation in 1998 was generally below average at both stations except during May 1998 which was far above average. The spike in precipitation during May 1998 may have stimulated a late surge of new growth in elk sedge, increasing the forage quality of mid-July 1998 samples at both study areas. Additionally, early to mid winter (November-January) precipitation was at or below average in 1997 but well above average in 1998 at both stations. High winter precipitation may have impacted the mid-January forage quality of elk sedge during 1998. The year effect on CP noted at Bridge Creek but not at Starkey may be related to station differences in early summer precipitation. Precipitation amounts near Bridge Creek during June and July of 1997 were much higher than the long-term means but were near normal at Starkey.

\section{Conclusions}

Although sampling date and plant community effects were detected, the forage quality of elk sedge appeared relatively stable compared to other native forages. Elk sedge has been considered as a "level component" forage or a forage that maintains at least moderate forage quality through all seasons and may help sustain herbivore diet quality during dormancy of other forage species (Huston and Pinchak 1991, p. 48). Crude protein is commonly regarded as an effective index of overall nutritional quality in forages (Van Soest
1982). Crude protein of $7.5 \%$ has been considered a nutritional threshold for maintenance of wild and domestic herbivores (Ganskopp and Bohnert 2001). Spring-early summer CP content in the dominant grasses of the interior Pacific Northwest and northern Great Basin is generally elevated well above this threshold. Crude protein levels rapidly decline, however, as these grasses enter reproductive phenological stages (Fig. 2). By July, $\mathrm{CP}$ in these species typically drops below $7.5 \%$ and continues to decline through summer and fall (Ganskopp and Bohnert 2001). Crude protein in elk sedge from the Blue Mountains of Oregon remains above $7.5 \%$ at least through mid July, allowing cattle, elk and other herbivores to continue on a maintenance diet later into the season. Elk sedge may also serve as a critical forage source during late fall and winter when the CP content of other graminoids is extremely low (3 to 4\%) (Clark et al. 2000, Ganskopp and Bohnert 2001).

\section{Literature Cited}

Anderson, E.W. and R.J. Scherzinger. 1975. Improving quality of winter range forage for elk by cattle grazing. J. Range Manage. 28:120-125.

Bailey, D.W., J.E. Gross, E.A. Laca, L.R. Rittenhouse, M.B. Coughenour, D.M. Swift, and P.L. Sims. 1996. Mechanisms that result in large herbivore grazing distribution patterns. J. Range Manage. 49:386-400.

Bryant, L.D. 1993. Quality of bluebunch wheatgrass (Agropyron spicatum) as a winter range forage for Rocky Mountain elk (Cervus elaphus nelsoni) in the Blue Mountains of Oregon. Ph.D. Diss.. Oregon State Univ., Corvallis, Ore.

Clark, P.E., W.C. Krueger, L.D. Bryant, and D.R. Thomas. 2000. Livestock grazing effects on forage quality of elk winter range. J. Range Manage. 53:97-105.

Driscoll, R.S. 1957. Effects of intensity and date of herbage removal on herbage production of elk sedge. M.S. Thesis. Colorado State Univ., Fort Collins, Colo.

Edgerton, P.J. and J.G. Smith. 1971. Seasonal forage use by deer and elk on the Starkey Experimental Forest and Range, Oregon. USDA-For. Serv. Res. Pap. PNW112. PNW Res. Sta., Portland, Ore.

Ganskopp, D. and D. Bohnert. 2001. Nutritional dynamics of 7 northern Great Basin grasses. J. Range Manage. 54:640-647.

Goering, H.K., and P.J. Van Soest. 1970. Forage fiber analyses (apparatus, reagents, procedures, and some applications). Agr. Handb No. 379. USDA Agr. Res. Serv., Washington, D.C. 
Hall, F.C. 1973. Plant communities of the Blue Mountains in eastern Oregon and southeastern Washington. USDA For. Serv. R6 Area Guide 3-1. USDA For. Serv. Region 6, Portland, Ore.

Hobbs, N.T. and D.M. Swift. 1985. Estimates of habitat carrying capacity incorporating explicit nutritional constraints. J. Wildl. Manage. 49:814-822.

Holechek, J.L., M. Vavra, J. Skovlin, and W.C. Krueger. 1982. Cattle diets in the Blue Mountains of Oregon. II. Forests. J. Range Manage. 35:239-242.

Huston, J.E. and W.E. Pinchak. 1991. Range animal nutrition, p. 27-63. In: R.K. Heitschmidt and J.W. Stuth (eds.), Grazing management: an ecological perspective. Timber Press, Portland, Ore.

Krueger, J.K. and D.J. Bedunah. 1988. Influence of forest site on total nonstructural carbohydrate levels of pinegrass, elk sedge, and snowberry. J. Range Manage. 41:144-149.

Kufeld, R.C. 1973. Foods eaten by the Rocky Mountain elk. J. Range Manage. 26:106-113.

Larter, N.C. and C.C. Gates. 1991. Diet and habitat selection of wood bison in relation to seasonal changes in forage quantity and quality. Canadian J. Zool. 69:2677-2685.
McArthur, M.B. 1977. Seasonal food habits and diet quality of the Colockum elk herd in central Washington. M.S. Thesis. Washington State Univ., Pullman, Wash.

McReynolds, S.J. 1977. Season elk food habits and diet quality in central Washington. M.S. Thesis. Washington State Univ., Pullman, Wash.

Pickford, G.D. and E.H. Reid. 1943. Competition of elk and domestic livestock for summer range forage. J. Wildl. Manage. 7:328-332.

Pinchak, W.E., M.A. Smith, R.H. Hart, and J.W. Waggoner, Jr. 1991. Beef cattle distribution patterns on foothill range. J. Range Manage. 44:267-275.

Robertson, J.B. and P.J. Van Soest. 1981. The detergent system of analyses and its application to human foods, p. 123-158. In: In: W.P.T. James and O. Theander (eds.) The analysis of dietary fiber. Marcell Dekker, New York, N.Y.

SAS. 1997. SAS/STAT Software: Changes and Enhancements through Release 6.12, SAS Institute Inc., Cary, N.C.

Satterthwaite, F.E. 1946. An approximate distribution of estimates of variance components. Biometrics Bull. 2:110-114.

Sheehy, D.P. 1987. Grazing relationships of elk, deer, and cattle on seasonal rangelands in northeastern Oregon. Ph.D. Diss. Oregon State Univ., Corvallis, Ore.
Skovlin, J.M. 1967. Fluctuations in forage quality on summer range in the Blue Mountains. USDA For. Serv. Res. Paper PNW-44. PNW For. and Range Exp. Sta., Portland, Ore.

Skovlin, J.M. 1991. Fifty years of research progress: a historical document on the Starkey Experimental Forest and Range. USDA For. Serv. Gen. Tech. Report PNWGTR-266. PNW Res. Sta., Portland, Ore.

Skovlin, J.M. and M. Vavra. 1979. Winter diets of elk and deer in the Blue Mountains, Oregon. USDA For. Serv. Res. Pap. PNW260. PNW Res. Sta., Portland, Ore.

Skovlin, J.M., R.W. Harris, G.S. Strickler, and G.A. Garrison. 1976. Effects of cattle grazing methods on ponderosa pine-bunchgrass range in the Pacific Northwest. USDA For. Serv. Tech. Bull. 1531. U.S. Gov. Printing Off., Washington, D.C.

Stoddart, L.A. 1946. Some physical and chemical responses of Agropyron spicatum to herbage removal at various seasons. Utah Exp. Sta. Bull. 324. Utah State Univ., Logan, Ut.

Tukey, J.W. 1953. The problem of multiple comparisons. Unpublished manuscript. Princeton Univ., Princeton. N.J.

Van Soest, P.J. 1982. Nutritional ecology of the ruminant. O \& B Books, Inc., Corvallis, Ore. 